\title{
Dying to serve: the mass burials at Kerma
}

\author{
Margaret Judd ${ }^{1} \&$ Joel Irish $^{2}$
}

High ranking burial mounds in Bronze Age Sudan featured burials in a corridor leading to the central burial - supposedly of a king. Were the 'corridor people prisoners captured during periodic raids on Egypt, or local retainers who followed their king in death? The authors use the skeletal material to argue the second hypothesis - coincidentally that advanced by George Reisner, the original excavator.

Keywords: Sudan, Nubia, Kerma, sacrifice, ethnicity

\section{Introduction}

Kerma, the Bronze Age capital of the Kushite Kingdom in Upper Nubia (Sudan), was the site of the earliest African complex society outside of Egypt, and Egypt's adversary for control of the Nile trade. Kerma (the modern name of the site) was equally renowned for its distinctive funerary landscape: $80-90 \mathrm{ha}$ of tumuli presided over by two imposing mud-brick temples. Mass interments of hundreds of individuals occurred within the corridors of the largest of these tumuli that also held the corporeal remains of the king (Figure 1). There has been much speculation about the identity of these 'corridor people' based on the implicit assumption that they were contemporaries of the king and not, for example, interred later - either within the existing structure or an addition to the central chamber. The traditional view is that they were loyal subjects. Specifically, it was speculated that they were mostly female members of the king's entourage and other persons, such as servants, family, trusted friends and administrators, who voluntarily accompanied their king to his grave (Adams 1977; Bonnet 1990b; O'Connor 1993; Kendall 1997; Edwards 2004). This interpretation rests solely on Reisner's (1923a) authoritative opinion following his excavation of the site nearly 100 years ago, from 1913-16. It is the purpose of the present report to test the likelihood of his view.

Egyptian texts are unusually silent about the culture of 'wretched' Kush as they preferred to call this territory (Adams 1977; Smith 2003; Edwards 2004) - most likely to not empower their enemy. However, a recently discovered inscription in Governor Sobeknakht's tomb at Elkab, Egypt, dated to the end of the Classic Kerma period (1550 BC), provides evidence of the northerly extent of Kerma's military activities (Davies 2003). This inscription recounts the Kushite penetration of Egypt to Elkab, and their plunder-laden return to Kerma. It was

\footnotetext{
1 Department of Anthropology, University of Pittsburgh, Pittsburgh, PA 15260, USA (Email: mjudd@pitt.edu)

2 University of Alaska-Fairbanks, Department of Anthropology, 310 Eielson Building, PO Box 757720, Fairbanks, AK 99775-7720, USA (Email: ffjdi@uaf.edu)
} 


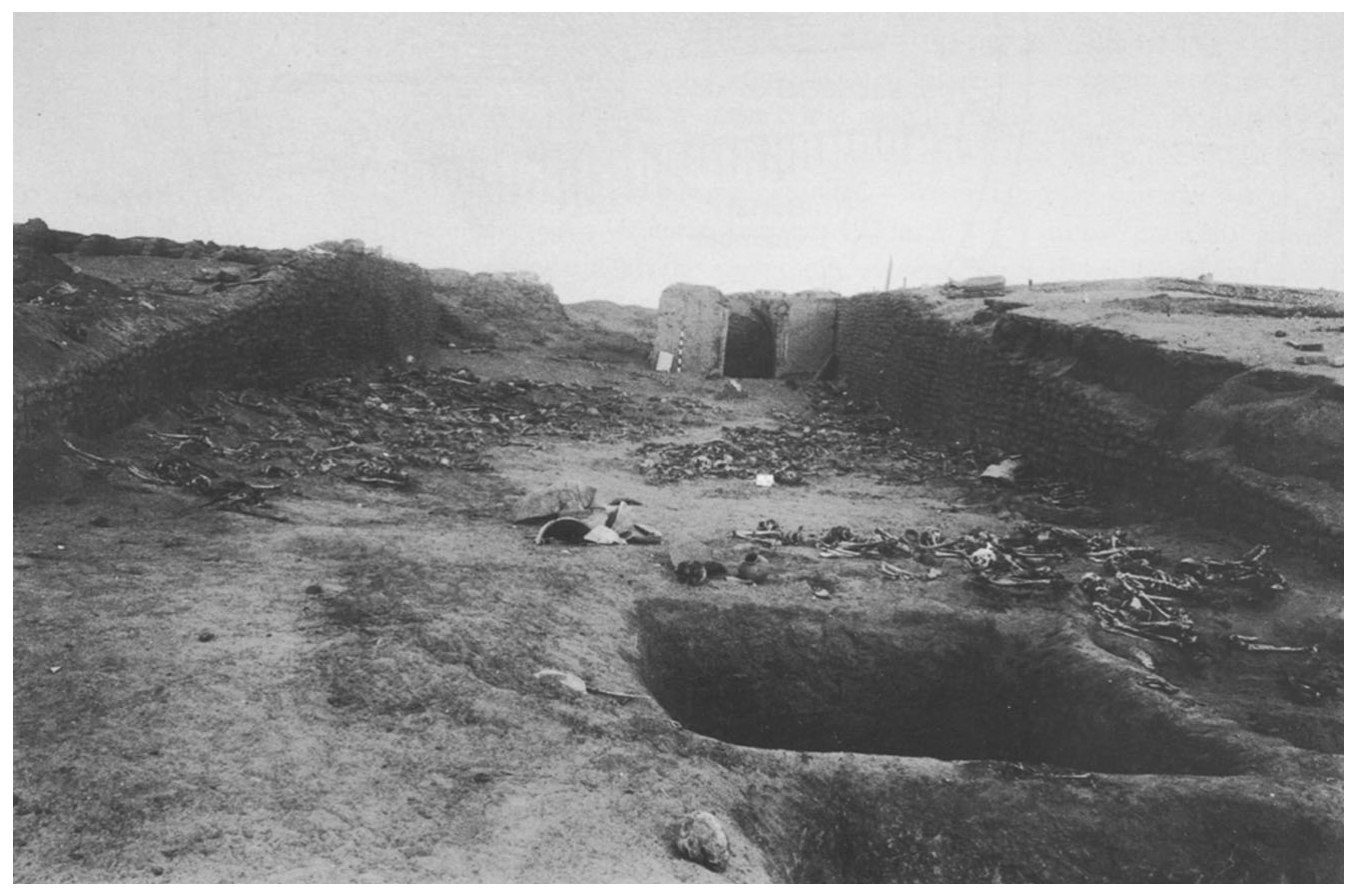

Figure 1. Central corridor B west of Tumulus KX, with king's chamber (after Reisner 1923a: Plate 20).

proposed that the monumental Egyptian statuary and stelae in the Kerma funerary corridors were trophies of this and other incursions, and were interred with the Kerma kings as a symbol of infinite Kushite supremacy (Davies 2003). Furthermore, this explanation may extend to the dead interred within these corridors, who may in fact have been the human victims of Kushite pillage.

Here we revisit Reisner's interpretation by testing three hypotheses involving the skeletal remains of people within their funerary contexts. If Reisner was correct, there should be no difference in the frequencies of skeletal trauma due to antemortem interpersonal violence and perimortem injuries among people in the corridors, versus those interred elsewhere, in what have been termed subsidiary burials. If the people interred in the corridor were indeed prisoners of war, they would have more likely been physically abused while alive and later forcibly interred or slaughtered. There should also be no significant difference genetically between individuals comprising the corridor and subsidiary burials, since both groups would have been drawn from the same local Kerman population. Assuming that phenetic similarity provides an estimate of genetic relatedness both groups should, based on comparisons of cranial measurements in the present study, share a close affinity. The Kushite burial configuration was distinct, so if burials within the corridor adhere to the Kushite orientation, posture and ritually placed indigenous grave goods they would be more probably Kerman, rather than captives from outside the region.

If the captive hypothesis is supported, Kerma may indeed prove to have been more powerful than previously thought, having been capable of herding captive Egyptians over an 
expanse of inhospitable territory during two centuries of growing Kushite military power. If it is rejected, then Reisner's speculations may be supported, i.e. the people interred within the corridor were Kermans who accompanied their king to the afterlife, willingly or unwillingly. In either case, the social identity of these individuals and circumstances of their death have broader implications for our interpretation of Kushite ideology

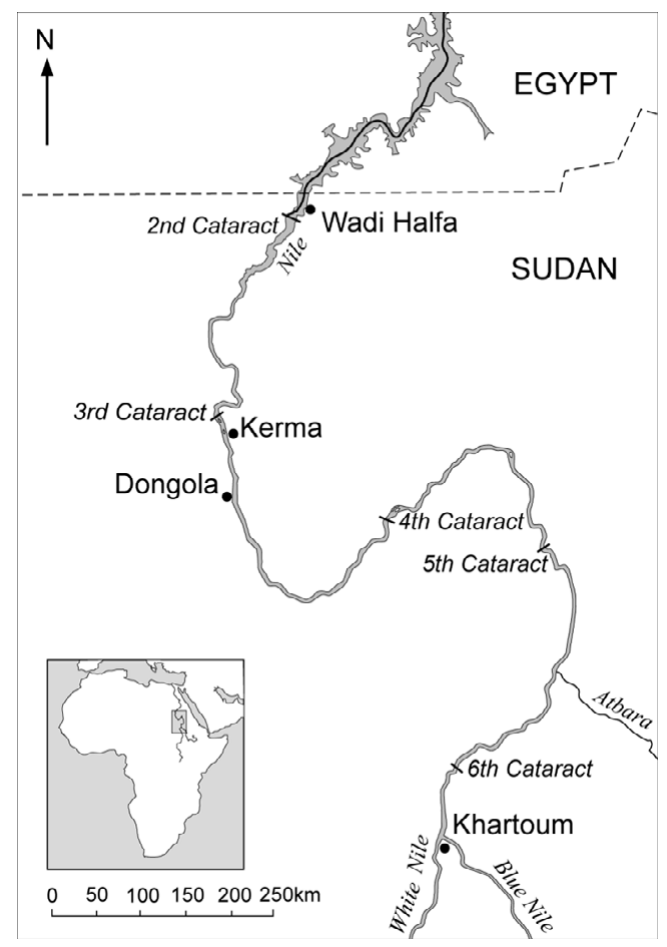

Figure 2. Map showing the location of Kerma. and the magnitude of the king's authority within the local and international political arena. Even if other interpretations prove to be valid (e.g. the subsidiary and corridor people are not contemporary) based on future archaeological evidence, the present hypothesis testing will still be useful in assessing the degree of biocultural affinity of individuals in the two burial contexts.

\section{Archaeological context}

Kerma (c. 3000 to the mid-fifteenth century BC) was strategically located just south of the Nile's third cataract (Figure 2); this locale facilitated a trade relationship with Egypt that, by 2200 $\mathrm{BC}$, led to substantial prosperity (Breasted 1962). Kerma provided luxuries such as exotic animals, gold and ebony to the Egyptians, while Kushite mercenaries were recruited to safeguard trade (Fischer 1961, 1962; Adams 1977; Bonnet 1990a). Egypt reciprocated by providing Kerma with endproducts crafted by skilled Egyptians. Over the next 500 years Kerma experienced considerable economic and political expansion, and periodically attacked Egypt during episodes of political upheaval that plagued the pharaohs of the early second millennium BC.

During the Classic Kerma period (c. 1750 until its conquest by Thutmose I of Thebes in the Eighteenth Dynasty) ten monumental tumuli were constructed in what Reisner (1923a) termed the Egyptian Cemetery (Cemetery B, Figure 3). The largest tumulus, Tumulus X, measured $90 \mathrm{~m}$ in diameter and concealed a honeycombed network of mudbrick walls (Figure 4). Central corridors containing as many as 300 individuals bisected three of these structures, while the remaining seven contained chambers rather than corridors to hold multiple interments. Reisner (1923a) designated the central burial that led off the corridor as that of a king, who was laid out between two ox-hides on an intricately carved and mica-inlaid bed. The accompanying bodies in the king's chamber and corridors were placed on the floor, often in clusters, and covered with hide. Reisner (1923a) observed that the bodies were positioned in the indigenous Kushite manner: the individual was flexed on their right side and oriented so that the head was to the east 


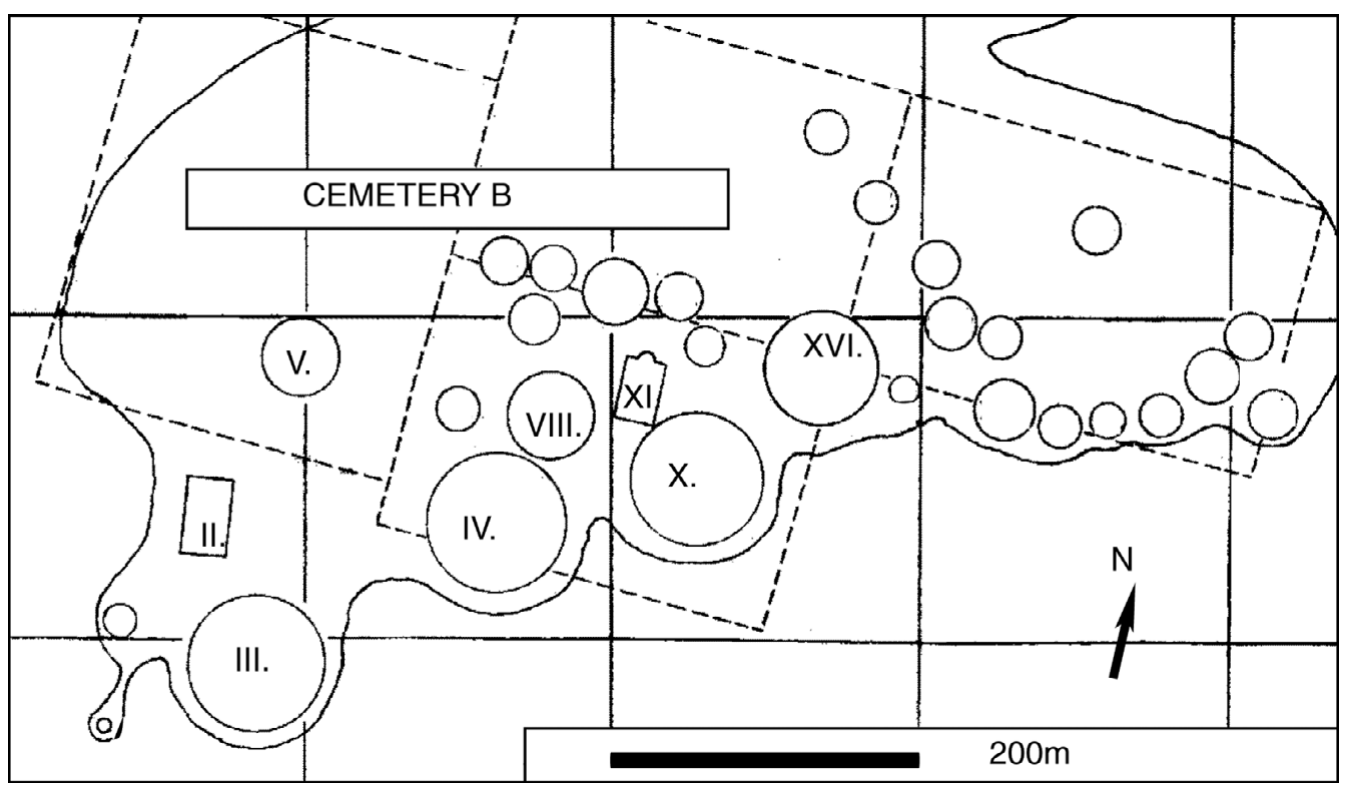

Figure 3. Cemetery B, the Egyptian Cemetery (adapted from Reisner 1923a: Plan II).

and the individual faced north. He recorded that some individuals were in a pose of 'fear,' with their hands positioned over their heads or having apparently attempted to hide under the central beds. Whether or not there was a time lapse between some interments is unknown.

Rows of cattle skulls flanked the south side of each tumulus, which were paved with mud-brick and covered with a pebble mosaic crowned by a central marble cone (Reisner 1923a; Bonnet 2000). The surrounding smaller tumuli emulated the royal tombs. The most important individual, believed by Reisner to be male, was placed on an ivory or mica-inlaid bed on the south side of the tomb and surrounded by an array of other humans and animals; the latter often included sheep or goats and an occasional dog. These animals were systematically placed on the west side of the pit, attired with a lead or ostrich feather headdress, dabbed with red ochre and appeared to be in a peaceful slumber. Simple subsidiary pit-burials were also cut into the royal tumuli and surrounding alluvium.

\section{Materials}

The skeletal sample from Kerma is curated in the Duckworth Laboratory at the University of Cambridge's bioanthropology department. To test our hypotheses it was essential to sort through Reisner's (1923a \& b) extensive site catalogue to determine the context of each skeleton available for analysis. The resulting two groups each contained the skeletal remains of males and females:

1. The corridor people: individuals who were buried en masse within the corridors or chambers of Tumuli III, IV, X, XVI and XVIII; and 


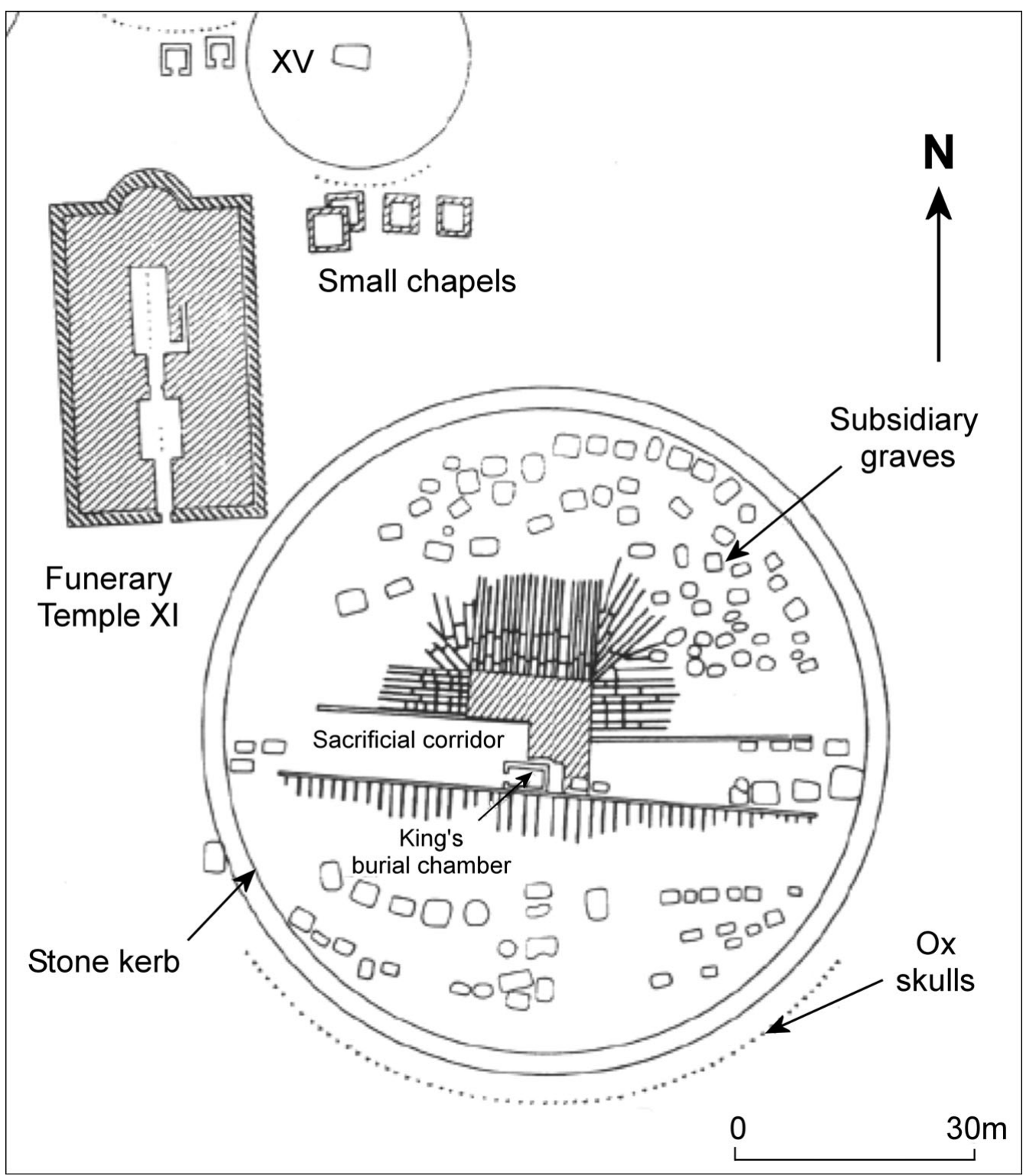

Figure 4. Plan of Tumulus KX and funerary chapel KXI (adapted from Kendall 1997: Figure 28).

2. The subsidiary people: individuals buried in graves cut into the above tumuli or in the smaller tumuli surrounding Tumuli III, IV and XVI. These burials frequently included more than one individual and may represent a secondary phase of sacrifice that followed the sealing of the royal tomb. However, the focus of this analysis is the differentiation in social structure between people interred within the corridors, and those buried outside the corridors. 
Table 1. Context of Kerma individuals used for each analysis.

\begin{tabular}{lccccc}
\hline & \multicolumn{2}{c}{ Corridor } & & \multicolumn{2}{c}{ Subsidiary } \\
\cline { 2 - 3 } Analysis & Males & Females & & Males & Females \\
\hline Postcranial trauma & 37 & 38 & & 57 & 91 \\
Skull trauma & 43 & 62 & & 61 & 150 \\
Craniometric & 30 & 50 & & 50 & 123 \\
\hline
\end{tabular}

It is estimated from Reisner's (1923a) report that at least 850 individuals were excavated; of these, skeletal remains of approximately 341 individuals are curated in the Duckworth Laboratory, although some are fragmentary. Only individuals over 18 years of age for whom a context and biological sex could be determined were included in this analysis. The biological sex of each individual was established using the protocol summarised by Buikstra and Ubelaker (1994). Prior research revealed that standard biological age cohorts (youth: 18-25 years, young adult: 25-35 years, middle adult: 35-50 years and mature adult: $50+$ years) were distributed similarly in both corridor and subsidiary contexts (Buzon \& Judd 2008). Though Reisner noted the presence of younger individuals, only the remains of approximately nine children were recovered. Because of this small sample size and the potential for differential burial treatment, children were excluded from analyses. Due to the nature of our hypotheses the methods, distribution of individuals by sex, and results of each section are presented separately (Table 1).

\section{Trauma analysis}

Trauma was considered first to determine if there were any perimortem injuries or antemortem evidence of torture and/or long-term abuse to suggest the corridor people were prisoners of war or vulnerable lower classes. To infer behaviour, it is necessary to determine whether the injury was due to violence or accident. The ambiguous nature of injuries caused by accidental and intentional incidents observed on skeletal remains has been deliberated by many bioarchaeologists (Lovell 1997; Alvrus 1999; Jurmain 1999; Judd 2002, 2004, 2008; Novak 2006); the array of injuries linked to intentional actions include: cranial blunt force trauma, direct force forearm (parry) fractures, sharp force trauma, projectile trauma and multiple injuries. Traumatised small bones such as the ribs, vertebrae and extremities were included with multiple traumas for this study. The injuries summarised here derive from a detailed trauma analysis published elsewhere (Judd 2004). A chi-square analysis was used to assess differences in trauma frequencies, while independent samples t-tests compared metric variations in lesions when possible.

The demographic profile and injury patterns observed for each sex between burial contexts and between the sexes within each context yielded few significant differences (Tables 2 and 3). There was no evidence of unambiguous perimortem trauma in either group. Subsidiary males bore more injuries and had the highest incidence of multiple and long bone traumas. All male ulna injuries exhibited the parry fracture signature, while approximately a third of female ulna injuries were attributed to direct force in both contexts. Antemortem skull trauma was more frequent among those within the corridors, although this relationship is 
Table 2. Trauma analysis results showing individuals affected, observed and frequency.

\begin{tabular}{lcclcc}
\hline & \multicolumn{2}{c}{ Corridor } & & \multicolumn{2}{c}{ Subsidiary } \\
\cline { 2 - 3 } \cline { 6 - 6 } Trauma analysis & Males & Females & & Males & Females \\
\hline Long bones & $6 / 292(2.1)$ & $6 / 328(1.8)$ & & $24 / 511(4.7)$ & $12 / 898(1.3)$ \\
Ulna & $5 / 39(12.8)$ & $2 / 46(4.3)$ & & $7 / 70(10.0)$ & $2 / 121(1.7)$ \\
Skull & $8 / 38(21.1)$ & $11 / 55(20.0)$ & & $7 / 48(14.6)$ & $8 / 130(6.2)$ \\
Multiple trauma & $6 / 17(35.3)$ & $9 / 22(40.9)$ & & $18 / 27(66.7)$ & $12 / 38(31.6)$ \\
Individuals with trauma & $16 / 42(37.1)$ & $22 / 62(35.5)$ & & $27 / 61(44.3)$ & $38 / 150(25.3)$ \\
\hline
\end{tabular}

Table 3. The $p$-values for each sex and between the sexes within each context.

\begin{tabular}{lcccc}
\hline Trauma analysis & Males & Females & Corridor & Subsidiary \\
\hline Long bones & .058 & .525 & .839 & $\mathbf{. 0 0 0}$ \\
Ulna & .831 & .518 & .322 & $\mathbf{. 0 1 2}$ \\
Skull & .432 & $\mathbf{. 0 0 5}$ & .902 & .072 \\
Multiple trauma & $\mathbf{. 0 2 4}$ & .465 & .542 & $\mathbf{. 0 0 5}$ \\
All trauma & .472 & .136 & .856 & $\mathbf{. 0 0 7}$ \\
\hline
\end{tabular}

significant only among females; there was no significant difference in skull trauma frequency between the sexes for each context. A total of 52 discrete skull injuries were observed, with 45 located on the vault. Blunt force trauma accounted for about 66 per cent of all male, and 77 per cent of all female skull injuries. There was no significant difference between the distribution of vault injuries according to side. However, the right side was slightly favoured regarding blunt force trauma and the left was predisposed to sharp force trauma.

When all cranial lesions were considered, the areas of injuries ranged in size from 22.72 to $1232.24 \mathrm{~mm}^{2}$ among the corridor people, and 6.60 to $2053.26 \mathrm{~mm}^{2}$ among the subsidiary people. An independent samples t-test revealed no significant difference in lesion areas between individuals of different burial contexts when the areas of all lesions were compared $(\mathrm{t}=-0.23, p=0.82)$; moreover, there was no significant difference in injury areas when only vaults were compared $(\mathrm{t}=-0.53, p=0.60)$. Similar weapons, likely including the hands and feet, were used to inflict injuries among individuals in both contexts.

Males buried outside the corridor experienced a higher frequency of multiple injuries than their contemporaries. When the total number of injured individuals was considered, there was no significant difference in trauma frequency between contexts. Males suffered more than their female counterparts in all injury categories, which is a cross-cultural phenomenon in modern societies (Judd 2004). The corridor people did not exhibit significantly greater frequencies of trauma, more severe injuries or distinct injury patterns when compared to the subsidiary people. Individuals interred within the corridor were at no greater injury risk of interpersonal violence during daily life than those in the subsidiary graves.

The trauma analysis results do not reject the hypothesis concerning frequencies of skeletal trauma. There was no evidence that the corridor people had been abused, tortured or 
Table 4. The 13 standard cranial measurements used in the study.

\begin{tabular}{ll}
\hline Cranial measurements & Cranial landmarks \\
\hline Maximum length & Glabella-opisthocranion \\
Maximum breadth & Euryon-euryon \\
Maximum height & Basion-bregma \\
Cranial base length & Basion-nasion \\
Basion-prosthion length & Basion-prosthion \\
Upper facial height & Nasion-prosthion \\
Nasal height & Nasion-nasospinale \\
Nasal breadth & Alare-alare \\
Bizygomatic breadth & Zygion-zygion \\
Minimum frontal breadth & Frontotemporale-frontotemporale \\
Interorbital at dacryon & Dacryon-dacryon \\
Orbital breadth & Dacryon-ectoconchion \\
Orbital height & Perpendicular to above \\
\hline
\end{tabular}

were frequent participants in interpersonal violence. In fact, the subsidiary males exhibited higher frequencies of trauma in many instances, although this was not always significant. No evidence of perimortem trauma or funerary treatment, such as defleshing, was observed for either group. If the corridor people were sacrificed or unwilling to go to their deaths, the method of death did not leave any skeletal evidence.

\section{Craniometric analysis}

To determine if the subsidiary and corridor people were derived from the same or different populations, i.e. whether the latter were Kerman or perhaps foreign slaves or prisoners, a craniometric comparison was undertaken between groups. Nonmetric dental traits are also useful for assessing inter-group affinity; such data were collected by the second author. Unfortunately, whereas a sufficient number of teeth remain in the Kerma crania to estimate relatedness of the combined sample to others in Nubia (see Irish 2005) and elsewhere, there are too many missing post-mortem (presumably from $>80$ years of handling after excavation) to assess intra-sample variation. Nevertheless, following many researchers (e.g. Martin \& Saller 1959; Howells 1966, 1989; Froment 1992; Hanihara 1992, 1996, 2000; Brace et al. 2001; Roseman \& Weaver 2003; Pietrusewsky 2004), it is assumed that cranial form corresponds with population affinity (i.e. reflects genetic relatedness). As such, up to 13 standard measurements of 253 crania recorded by Collett (1933) were compared to identify differences. Because of sexual dimorphism, male and female crania were analysed separately. These measurements are listed in Table 4 and described in Martin and Saller (1959) and Froment (1992). To quantify the comparisons, means, standard deviations, and coefficients of variation (COV) were computed by group. Independent samples t-tests were then performed. Lastly, discriminant analysis (Howells 1966; Froment 1992; Pietrusewsky 2004), using the direct entry method on 12 measurements, was employed; the interorbital at dacryon measurement was dropped from analysis because of numerous missing data. Mean substitution was used to replace other missing measurements. 
Results from the COV for the 13 subsidiary and corridor context measurements indicate that neither group was more variable than the other. If the sacrificial corridor victims were a mix of foreign slaves and prisoners, or a combination of foreigners and some Kerma inhabitants, one would expect greater craniometric variation relative

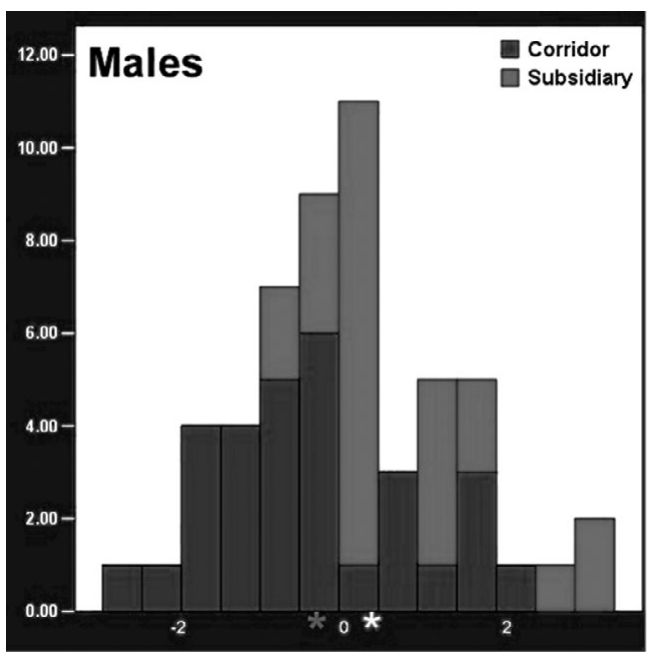

Figure 5. Stacked histogram of canonical discriminant function scores for the 30 corridor (black) and 50 subsidiary (grey) male crania, illustrating correct classification rate of 62.5 per cent. Asterisks denote corresponding group centroids of -0.38 and 0.2 , respectively.

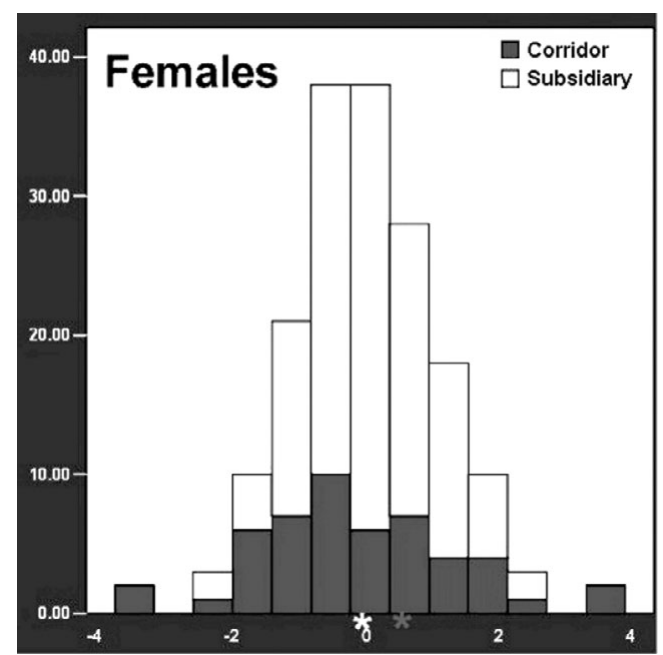

Figure 6. Stacked histogram of canonical discriminant function scores for the 50 corridor (black) and 123 subsidiary (white) female crania, illustrating correct classification rate of 58.4 per cent. Asterisks denote corresponding group centroids of 0.41 and -0.01 , respectively. to the subsidiary group. This is not the case. Moreover, there were no significant pairwise differences (i.e. $\leqslant 0.05$ ) between any measurements based on t-tests. Lastly, for males, discriminant analysis yielded a correct classification rate of 62.5 per cent between subsidiary and corridor crania based on the 12 measurements. This rate is just 12.5 per cent better than random assignment (i.e. 50-50 guessing), which also indicates little difference between groups. The corresponding Wilk's Lambda, which gauges robustness of the discriminant model, is large $(\lambda=0.69)$ and insignificant $(p=0.35)$ based on the chisquare test. In females the corresponding classification rate was reduced to 58.4 per cent - just 8.4 per cent better than random assignment $(\lambda=0.90, p=$ 0.93). This lack of differentiation is illustrated by the close proximity of group centroids, and the overlap of individuals in a stacked histogram of discriminant values (Figures 5 and 6). If the two groups were markedly different, there would be little or no overlap of these distributions.

The statistical analyses do not indicate any significant differences between the subsidiary and corridor people for either males or females. These findings suggest that the individuals in the corridors were not phenetically different from those comprising the subsidiary interments. There is nothing in the craniometric findings to suggest that the former came from a different population than the latter. Both sets of male and female subsamples were likely of the same, presumably Kerman, origin. 
Table 5. Ethnic comparisons showing number of Kushite objects and individuals interred (frequency).

\begin{tabular}{lccc}
\hline Kushite feature (Tumulus) & Corridor & Subsidiary & p-value \\
\hline Daggers (III, IV, X) & $38 / 462(8.2)$ & $75 / 494(15.2)$ & $\mathbf{. 0 0 9}$ \\
Throw sticks (X, XVI) & $5 / 364(1.4)$ & $9 / 283(3.2)$ & .117 \\
Headrests (X, XVI) & $20 / 364(5.5)$ & $25 / 283(8.8)$ & .270 \\
Kushite orientation (III, IV, X, XVI) & $255 / 373(68.4)$ & $226 / 322(70.2)$ & .604 \\
\hline
\end{tabular}

\section{Burial rite}

Indigenous Kushite artefacts as well as Egyptian scarabs, gold military awards, high quality alabaster vessels, bronze toiletries and jewellery were found in both contexts (Reisner $1923 \mathrm{~b}$ ). The attribution of artefacts to a specific individual is problematic owing to burial disturbances by looters and the en masse excavation of closely overlapping individuals. A second problem concerns the significance of the Egyptian artefacts. Were they the property of the deceased owing to the centuries old trade network with Egypt, or the more recently plundered items deposited in tandem with the Egyptian statuary to demonstrate Kushite domination? To further assess if the corridor people were ethnically Kushite, a simple analysis of body orientation and grave goods, as recorded by Reisner (1923a), was performed. He noted the burial position in relation to the traditional Kushite position, which was firmly entrenched in the Kerma culture by the Classic period (Geus 1991); any substantial deviation from the norm would be suspect and perhaps foreign, although differential circumstances surrounding death cannot be ruled out (Ucko 1969). Burial positions of articulated individuals and the total number of indigenous Kushite artefacts from four of the largest tumuli (Tumuli III, IV, X and XVI) were tallied from the report (Table 5).

Among undisturbed bodies, the Kushite position and orientation occurred with similar frequencies for both contexts: 68.4 per cent of the corridor and 70.2 per cent of the subsidiary individuals were interred in a flexed position, oriented east to west and faced north. Both contexts were distinctly Kushite. Minor deviations from this pattern may be attributed to grave robbing in antiquity; more pronounced divergences, such as the extended Egyptian-style position of some KIII corridor individuals, may be expected as Kerma maintained relationships with some regions of Egypt (Edwards 2004). Fluctuating expressions of ethnic affiliation may have been conferred in the burial orientation, but the majority of individuals conformed to the mainstream Kushite burial practices and ritual. Two notable demonstrations of personal identity included a pot-burial from Corridor B in Tumulus IV (Reisner 1923a) and a poorly constructed Egyptian style coffin from a subsidiary grave (Dunham 1982: ix).

The popularity of funerary artefacts varied temporally, but the Kushite ceremonial dagger was consistently present throughout the Classic Kerma period. Other traditional Kushite items, such as throw sticks and headrests, were underestimated due to their organic composition and destruction during looting. When the distribution of these three artefacts was compared, a significant difference existed only among the Kushite daggers. It is unlikely 
that such prestige would have been privileged upon a prisoner of war, particularly as the daggers were bound to the individual's waist or thigh as part of their funerary attire. Daggers were associated with four people in the corridors, and of these individuals one was a female; a throw stick was found with a second female. None of these individuals suffered skeletal trauma. Among those in subsidiary graves, five females and twelve males possessed daggers and none displayed injuries characteristic of violence. The association of these daggers does not necessarily mean that the artefact served as a weapon for the deceased, but may in fact have been symbolically empowered and unrestricted by the binary nature of biological sex. What we perceive as a weapon may have been linked to social status, power, occupation, kin group or serve another function. For example, the ambiguity of an artefact is illustrated by the simple wooden staff, which among the ancient Egyptians served as a walking aid, shepherd's 'tool', symbol of manhood, or a fighting stick (Loebl \& Nunn 1997). Similarly, the dark hardwood throw stick was highly prized among ancient dwellers of the Nile Valley; although they may have been brandished as a menacing weapon or hurled during warfare, throw sticks were frequently depicted in hunting or tribute scenes (Arkell 1939; Kendall 1988). The presence of daggers, throw-sticks and headrests in both burial contexts and with both sexes, supports a heterogeneous mixture of people.

\section{Discussion}

These findings suggest that large numbers of Kermans did accompany their king in death, but whether this was done willingly or not is unknown. There was no skeletal evidence of physical force to subdue reluctant participants, although soft tissue trauma resulting in death remains a possibility. A sedative may also have been involved, particularly when the arrangement of the interred animals is considered. The goats and dogs were placed in a position of slumber, rather than a position indicating a conscious reaction to being buried alive; no evidence of perimortem trauma was noted, either at Kerma or at any other Classic Kerma site (Chaix 1993; Grant 2001). But again, soft tissue trauma is possible; for example, a main artery could have been skillfully severed without nicking a bone. Suffocation as a form of sacrifice was not unknown, as Bonnet (1990b) recovered lambs stuffed into leather sacks. Still, no chemical or physical evidence of sedation was recovered within either context, such as the small cups associated with individuals from sacrificial pits at Ur (Woolley 1934: 35-6).

Ethnohistoric accounts and material culture exist to help elucidate ritual and dedicatory sacrifice among some ancient cultures, such as the Inca and Moche (Ceruti 2004; Sutter \& Verano 2007), but this is not the case at Kerma. The lack of documentation by the Kushites, Egyptians or any other historical chroniclers does not permit the isolation of a single motive for the Classic Kerma mass interments. However, the results discussed here further advance the social significance of these burials. While the sacrifice of prisoners-ofwar over a period of 200 years would have substantiated Kerma's prominence in Nile Valley politics, the fact that the corridor people formed a diverse socio-demographic profile of Kerman society has broader implications for this early African complex society. During the Classic Kerma period, Kushite ideology was clearly linked with the state, as the environs of the royal tumulus bore a metaphorical resemblance to that of the city of Kerma. Each 
royal tumulus was in fact a small city of the dead. The ruler in his discrete chamber was surrounded by a community of his subjects and households; the thousands of cattle skulls bordering the southern perimeter of the tumuli were the embodiment of Kerma's wealth and local economy, and a funerary temple presided over each sacred landscape. Correspondingly, $4.8 \mathrm{~km}$ away, the central temple (Western Defuffa) overlooked the king's palace, domestic structures, foundries, bakeries, storage pits and surrounding cattle pens (Bonnet 1990a \& b). The duality of the Kerman kings' supremacy in both life and death demonstrates that they were empowered with sufficient authority that even after death compelled masses of people, perhaps altruistically more so than willingly, to accompany them to their graves.

\section{Conclusions}

There were neither signs of violent perimortem skeletal trauma, such as cutmarks, multiple bludgeoning or stab wounds, nor obvious patterns of antemortem trauma or postmortem treatment within the corridor and subsidiary burial contexts. Craniometric analyses established the phenetic similarity of these groups. Similarly, the burial configuration was predominantly Kushite, and artefacts indigenous to Kush were found in both contexts, with many artefacts indicative of international trade or the debris of Egyptian plunder. The corridor people were selected or volunteered to accompany their king to his afterlife, and they reflected the composition of Kerma society and the magnitude of the king's authority. The likelihood is that Reisner was, in fact, correct.

\section{Acknowledgements}

We thank Vivian Davies (The British Museum) for suggesting a bioarchaeological investigation in response to his discovery at Elkab and Dr Alain Froment (Musée de l'Homme) for providing us with an initial database of Collett's (1933) cranial measurements. Marta Lahr and Robert Foley at the University of Cambridge generously provided access to the Kerma sample in the Duckworth Collections. Maggie Bellati is thanked for her helpfulness during the data collection. We are especially grateful for the assistance provided by Karen Excell (The Manchester Museum) and Rosalie David (The University of Manchester).

\section{References}

Arkell, A.J. 1939. Throw sticks? Sudan Notes and Records Part 2: 251.

Adams, W.Y. 1977. Nubia: corridor to Africa. Princeton (NJ): Princeton University Press.

Alvrus, A. 1999. Fracture patterns among the Nubians of Semna South, Sudanese Nubia. International Journal of Osteoarchaeology 9: 417-29.

Bonnet, C. 1990a. Limites et defenses de la ville, in C. Bonnet. (ed.) Kerma Royaume de Nubie: L'Antiquité Africaine au Temps des Pharaons: 43-6. Genève: Mission archéologique de L'Université De Genève Au Soudan.

- 1990b. Sépultures et coutumes funéraires, in C. Bonnet. (ed.) Kerma Royaume de Nubie: L'Antiquité Africaine au Temps des Pharaons: 69-86. Genève: Mission archéologique de l'Université de Genève au Soudan.
- 2000. Edifices et rites funéraires à Kerma. Paris: Éditions Errance.

Brace, C.L., A.R. Nelson, N. Seguchi, H. Oe, L. Sering, P. Qifeng, L. Yongyi \& D. Tumen. 2001. Old World sources of the first New World human inhabitants: a comparative craniofacial view. Proceedings of the National Academy of Sciences 98: 10017-22.

Breasted, J.H. 1962. Ancient records of Egypt. Volume 1. The First to the Seventeenth Dynasties. New York (NY): Russell and Russell.

BuIKSTRA, J.E. \& D.H. UBELAKER (ed.). 1994. Standards for data collection from human skeletal remains (Arkansas Archaeological Survey Research Series 44). Fayetteville (AR): Arkansas Archaeological Survey. 
BuZON, M.R \& M.A. JuDD. 2008. Investigating health at Kerma: sacrificial versus nonsacrificial individuals. American Journal of Physical Anthropology 136: 93-9.

Ceruti, C. 2004. Human bodies as objects of dedication at Inca mountain shrines north-western Argentina. World Archaeology 36: 103-22.

ChaIx, L. 1993. The archaeozoology of Kerma Sudan, in W.V. Davies \& R. Walker (ed.) Biological anthropology and the study of ancient Egypt: 175-85. London: British Museum Press.

Collett, M. 1933. A study of Twelfth and Thirteenth Dynasty skulls from Kerma, Nubia. Biometrical 25: 254-84.

DAVIES, W.V. 2003. Kush in Egypt: a new historical inscription. Sudan \& Nubia 7: 52-4.

Dunham, D. 1982. Excavations at Kerma. Part VI. Boston (MA): Boston Museum of Fine Arts.

EDWARDS, D.N. 2004. The Nubian past. London: Routledge.

FisCHER, H.G. 1961. The Nubian mercenaries of Gebelein during the First Intermediate Period. Kush 9: 44-80.

- 1962. The archer as represented in the First Intermediate Period. Journal of Near Eastern Studies 21: 50-2.

Froment, A. 1992. La différenciation morphologique de l'Homme moderne: congruence entre forme du crâne et répartition géographique du peuplement. Comptes-Rendus de l'Academie des Sciences 315(III): 323-9.

GEUs, F. 1991. Burial customs in the upper main Nile: an overview, in W.V. Davies \& R. Walker (ed.) Biological anthropology and the study of ancient Egypt: 57-73. London: British Museum Press.

Grant, A. 2001. The animal remains, in D.A. Welsby (ed.) Life on the desert edge: seven thousand years of settlement in the Northern Dongola Reach, Sudan (Sudan Archaeological Research Society 7): 544-55. London: Sudan Archaeological Research Society.

HaniHara, T. 1992. Dental and cranial affinities among populations of East Asia and the Pacific: the basic populations in East Asia, IV. American Journal of Physical Anthropology 88: 163-82.

- 1996. Comparison of craniofacial features of major human groups. American Journal of Physical Anthropology 99: 389-412.

- 2000. Frontal and facial flatness of major human populations. American Journal of Physical Anthropology 111: 105-34.

Howells, W.W. 1966. The Jomon population of Japan: a study by discriminant analysis of Japanese and Ainu crania (Papers of the Peabody Museum of Archaeology and Ethnology 57). Cambridge (MA): Harvard University.
- 1989. Skull shapes and the map: craniometric analyses in the dispersion of modern Homo (Papers of the Peabody Museum of Archaeology and Ethnology 79). Cambridge (MA): Harvard University Press.

IRISH, J.D. 2005. Population continuity versus discontinuity revisited: dental affinities among Late Paleolithic through Christian era Nubians. American Journal of Physical Anthropology 128: 520-35.

JuDD, M.A. 2002. Ancient injury recidivism: an example from the Kerma period of ancient Nubia. International Journal of Osteoarchaeology 12: 89-106.

-2004 . Trauma in the city of Kerma: ancient versus modern injury patterns. International Journal of Osteoarchaeology 14: 34-51.

- 2008. The parry problem. Journal of Archaeological Science 35: 1658-66.

JURMAIN, R.1999. Stories from the skeleton. Behavioral reconstruction in human osteology. Amsterdam: Gordon \& Breach.

KendalL, T. 1988. Ethnoarchaeology in Meroitic studies. Merotica 10: 625-745.

- 1997. Kerma and the Kingdom of Kush 2500-1500 BC: the archaeological discovery of an ancient Nubian empire. Washington (DC): National Museum of African Art, Smithsonian Institution.

Loebl, W. \& J. NunN. 1997. Staffs as walking aids in ancient Egypt and Palestine. Journal of the Royal Society of Medicine 90: 450-4.

LOVELL, N.C. 1997. Trauma analysis in paleopathology. Yearbook of Physical Anthropology 40: 139-70.

MARTIN, R. \& K. SALLER. 1959. Lehrbuch der Anthropologie in systematischer Darstellung. Stuttgart: Fischer Verlag.

NovaK, S.A. 2006. Beneath the facade: a skeletal model of domestic violence, in R. Gowland \& C. Knusel (ed.) Social archaeology and funerary remains: 239-52. Oxford: Oxbow.

O'CONNOR, D. 1993. Ancient Nubia: Egypt's rival in Africa. Philadelphia (PA): University Museum of Archaeology and Anthropology, University of Pennsylvania.

PIETRUSEWSKY, M. 2004. Multivariate comparisons of female cranial series from the Ryukyu Islands and Japan. Anthropological Science 112(3): 199-211.

ReISNer, G.A. 1923a. Excavations at Kerma. Parts I-III. Cambridge (MA): Harvard African Studies.

- 1923b. Excavations at Kerma. Parts IV-V. Cambridge (MA): Harvard African Studies.

Roseman, C.C. \& T.D. WeAver. 2003. Multivariate apportionment of global human craniometric diversity. American Journal of Physical Anthropology 125: 257-63. 
SMITH, S.T. 2003. Wretched Kush. London:

Routledge.

SUTTER, R.C. \& J.W. Verano. 2007. Biodistance analysis of Moche sacrificial victims from Huaca de la Luna Plaza 3C: matrix method test of their origins. American Journal of Physical Anthropology 132: 193-206.
UСКО, P.J. 1969. Ethnography and archaeological interpretation of funerary remains. World Archaeology 1: 262-80.

Woolley, C.L. 1934. Ur excavations. Volume 2: The Royal Cemetery. London: Oxford University Press. 